\title{
The maximum capacity of the bovine liver to excrete manganese in bile, and the effects of a manganese load on the rate of excretion of copper, iron and zinc in bile
}

\author{
BY EVELINE D. HALL* AND H. W. SYMONDS \\ Agricultural Research Council, Institute for Research on Animal Diseases, \\ Compton, Newbury, Berks, RG16 0NN
}

(Received 27 August 1980 - Accepted 14 January 1981)

\begin{abstract}
1. The maximum capacity of the bovine liver to excrete manganese in bile was determined in three Friesian-cross steers surgically prepared to allow bile flow-rate to be measured and samples collected. Plasma Mn concentrations were increased by infusing manganese chloride solutions into a jugular vein and the biliary excretion rates of $\mathrm{Mn}$, copper, zinc and iron were measured.

2. The maximum capacity of the liver to excrete $\mathrm{Mn}$ in bile was exceeded at an infusion rate of approximately $4000 \mu \mathrm{g} \mathrm{Mn} / \mathrm{min}$, and at this rate there was a significant decrease in the concentration of $\mathrm{Cu}, \mathrm{Fe}$ and $\mathrm{Zn}$ in bile. The maximum concentration (mean $\pm \mathrm{sE}$ ) of $\mathrm{Mn}$ in bile was $193 \pm 19 \mu \mathrm{g} / \mathrm{ml}$, and the maximum excretion rate (mean \pm SE) was $1210 \pm 130 \mu \mathrm{g} / \mathrm{min}$ for the three animals. There was no reduction in bile flow or evidence of liver damage as a result of the infusions.
\end{abstract}

Manganese toxicity and deficiency occur naturally in ruminants and have been produced experimentally (Bentley \& Phillips, 1951; Rojas et al. 1965; Cunningham et al. 1966; Bourne, 1967; Egan, 1972; Ford, 1972; Hidiroglou, 1979). The concentrations of $\mathrm{Mn}$ in blood and tissue are normally very low $(0.02 \mu \mathrm{g} / \mathrm{ml}$ blood, $0.2 \mu \mathrm{g} / \mathrm{g}$ muscle), although dietary $\mathrm{Mn}$ concentrations may exceed $100 \mathrm{mg} / \mathrm{kg}$. The homoeostatic mechanisms of the body therefore act principally to prevent excess Mn entering the systemic circulation and the major sites of control are the gut and liver. Over wide ranges of dietary Mn content only 0.5-1\% of dietary $\mathrm{Mn}$ is absorbed from the small intestine (Sansom et al. 1978). The absorbed Mn reaches the liver through the portal vein, and is almost completely removed during the first passage of the blood through the liver (Gibbons et al. 1976). Mn is the only trace element known to be treated in this manner. Most of the Mn removed by the liver is excreted in bile (Carter et al. 1974).

There must be a limit to the capacity of the liver to remove $\mathrm{Mn}$ from the blood and excrete it in bile since abnormally high systemic blood $\mathrm{Mn}$ concentrations and $\mathrm{Mn}$ toxicity do occur. High Mn concentrations in the systemic circulation interfere with the metabolism of other minerals (eg. copper and zinc) (Gubler et al. 1954; Järvinen \& Ahlström, 1975; Ivan \& Grieve, 1975) and with the metabolism of monoamines in the brain causing severe neurological syptoms (Kimura et al. 1978; Leach \& Lilburn, 1978). Excessive Mn uptake by the liver can cause liver damage and cholestasis particularly when plasma bilirubin concentrations are increased (Witzleben et al. 1968; Witzleben, 1971). The maximum capacity of the liver to extract $\mathrm{Mn}$ and prevent toxicity is unknown; a study was therefore undertaken to determine the maximum capacity of the bovine liver to excrete $\mathrm{Mn}$ in bile, and the effects of large quantities of $\mathrm{Mn}$ on bile flow and the biliary excretion of the trace elements $\mathrm{Cu}$, iron and $\mathrm{Zn}$. This information should indicate whether the liver's capacity to extract and excrete $\mathrm{Mn}$ is likely to be exceeded under normal conditions of husbandry.

\footnotetext{
*Recipient of Agricultural Research Council Postgraduate Award.
} 


\section{MATERIALS AND METHODS}

\section{Animals}

Three Friesian-cross steers (A, B and C) aged between 12 and 18 months were used. Each had its duodendum surgically altered to allow bile to be collected and its rate of flow measured. The procedure entailed isolating, from the rest of the duodenum, that section into which the common bile duct entered, and diverting the bile entering this isolated section back into the duodenum via a re-entrant cannula (Symonds, Mather \& Hall, unpublished procedure). The animals remained healthy and grew normally, but to ensure that they had recovered completely they were not used until $4-6$ weeks after surgery. The experiment took 4-5 months to complete on each animal. The weights of the steers $\mathrm{A}, \mathrm{B}$ and $\mathrm{C}$ at the beginning of the experiment were 219,279 and $240 \mathrm{~kg}$, and at the end 355,406 and $339 \mathrm{~kg}$ respectively. They were given a hay and dairy cake ration to give a gain of approximately $25 \mathrm{~kg}$ body-weight/month. The average concentrations of $\mathrm{Mn}, \mathrm{Cu}, \mathrm{Fe}$ and $\mathrm{Zn}$ in the hay were $127,5 \cdot 8,182$ and $21 \mu \mathrm{g} / \mathrm{g} \mathrm{DM}$, and in the dairy cake $107,39,247$ and $67 \mu \mathrm{g} / \mathrm{g} \mathrm{DM}$ respectively.

\section{Infusion procedure}

The systemic plasma concentration of $\mathrm{Mn}$ was increased by infusing manganese chloride solution at a constant rate into a jugular vein for $6 \mathrm{~h}$ using a Harvard Syringe Pump (Harvard Apparatus, Massachusetts, USA). The initial infusion rate of $\mathrm{Mn}$ was $30 \mu \mathrm{g} / \mathrm{min}$ for animal $C$ and $70 \mu \mathrm{g} / \mathrm{min}$ for animals $A$ and $B$. The rate of infusion was increased in succesive experiments at intervals of at least 2 weeks until there was no further increase in biliary Mn concentration, when it was assumed that the capacity of the liver to excrete $\mathrm{Mn}$ had been exceeded. Saline ( $9 \mathrm{~g}$ sodium chloride/l) was infused before the first infusion of $\mathrm{MnCl}_{2}$ to each steer to determine daily variations in bile flow and biliary $\mathrm{Mn}, \mathrm{Cu}, \mathrm{Fe}$ and $\mathrm{Zn}$ concentrations.

\section{Bile and plasma collection}

During experiments bile was collected into a bag attached to a harness on the animal. The volume was measured every $30 \mathrm{~min}$ to determine flow-rate and a small sample taken for analysis. The remainder of the bile was returned to the duodenum to ensure that the enterohepatic circulation of bile salts was maintained. The removal of the small volume of bile for analysis had a negligible effect on bile flow. Bile flow-rate was measured during each $6 \mathrm{~h}$ infusion, for $1 \mathrm{~h}$ before and after the infusion and for $3 \mathrm{~h}$ during the day before and the day after each infusion of $\mathrm{Mn}$. After $6 \mathrm{~h}$ infusions of $73.2 \mu \mathrm{g} \mathrm{Mn} / \mathrm{min}$ and $1760 \mu \mathrm{g}$ $\mathrm{Mn} / \mathrm{min}$ in animals $\mathrm{B}$ and $\mathrm{C}$ respectively bile flow and $\mathrm{Mn}$ excretion were measured for a further $9 \mathrm{~h}$.

During each infusion three $20 \mathrm{ml}$ blood samples were collected at $2 \mathrm{~h}$ intervals by venepuncture into bottles containing 100 i.u. heparin, and the plasma was removed after centrifugation.

\section{Preparation of solutions for infusion}

Pyrogen-free solutions were prepared as follows. The $\mathrm{MnCl}_{2}$ was first dried at $200^{\circ}$ for $24 \mathrm{~h}$ to remove the water of crystallization and then sealed into glass vials in an atmosphere of nitrogen and heated to $400^{\circ}$ overnight. It was then dissolved in an isotonic saline solution made up in double-glass distilled water. The solution was finally passed under pressure through a $45 \mu \mathrm{m}$ pore filter held in an autoclaved millipore sterilizing filter holder (Millipore (UK) Ltd, London) into a sterile bag.

\section{Analyses}

Trace elements. $\mathrm{Mn}, \mathrm{Fe}, \mathrm{Cu}$ and $\mathrm{Zn}$ concentrations in bile and blood plasma were determined directly by flame atomic absorption using a 751 or 107 Perkin-Elmer Atomic 
Absorption Spectrophotometer (Perkin Elmer Ltd, Beaconsfield, Bucks). Food samples were first dry ashed, and digested in $2 \mathrm{M}$-hydrochloric acid before the concentrations of trace elements were determined by atomic absorption spectrophotometry.

Bilirubin. Total plasma bilirubin concentrations were measured by an automated procedure based on the method of Jendrassik \& Grof (1938) as adapted by Gambino \& Schreiber (1964).

Enzymes. The activities of sorbitol dehydrogenase (SHD; EC 1.1.1.4), glutamate dehydrogenase (GDH; $E C$ 1.4.1.3), $\gamma$-glutamyl transpeptidase $(\gamma \mathrm{GT} ; E C 2.3 .2 .2)$ and creatine phosphokinase (CK; EC 2.7.3.2) were measured using test kits (Boehringer Corporation, London) on a Vitatron Automatic Kinetic Enzyme and Substrate Analyser (MSE Scientific Instruments, Crawley, Sussex).

\section{Statistical analysis}

Bile flow-rates and concentrations of $\mathrm{Cu}, \mathrm{Fe}$ and $\mathrm{Zn}$ in bile during the infusions were analysed by split-plot analysis of variance to determine differences due to animal, treatment and time.

When calculating the excretion of infused $\mathrm{Mn}$, the basal $\mathrm{Mn}$ excretion measured in the hour before each infusion was subtracted from the Mn excreted during the infusion. Any variation in $\mathrm{Cu}, \mathrm{Fe}$ and $\mathrm{Zn}$ concentrations in the bile, which may have been due to variations in the trace element concentrations in the diet, were eliminated for statistical analysis of the results by expressing values during the infusions as percentages of the control concentrations measured before the start of each infusion.

\section{RESULTS}

At each infusion rate the maximum concentration in bile was reached after approximately $3 \mathrm{~h}$, and remained stable at this concentration for the next $3 \mathrm{~h}$ of infusion. The rates at which $\mathrm{Mn}$ was infused, the mean concentration and excretion rates of $\mathrm{Mn}$ in bile during the last $3 \mathrm{~h}$ of the infusions, and the plasma $\mathrm{Mn}$ concentrations during the last $3 \mathrm{~h}$ of the infusions are shown in Table 1. For each infusion rate, except the highest in each animal, the mean ( \pm SE) percentage of Mn excreted in bile was $67.5 \pm 2.5$ of that infused/min. At the highest infusion rates a lower percentage of the infused Mn $(22-31.5 \% / \mathrm{min})$ was excreted in bile, indicating that the maximum excretion rate of $\mathrm{Mn}$ had been attained. The mean ( $\pm \mathrm{SE}$ ) maximum concentration of $\mathrm{Mn}$ in bile and the mean ( $\pm \mathrm{SE})$ maximum excretion rate, calculated from the two highest infusion rates into each steer, were $193 \pm 19 \mu \mathrm{g} / \mathrm{ml}$ and $1210 \pm 130 \mu \mathrm{g} / \mathrm{min}$ respectively.

The mean ( $\pm \mathrm{sE})$ percentage of the total infused $\mathrm{Mn}$ recovered in bile during the $6 \mathrm{~h}$ infusion plus $1 \mathrm{~h}$ post-infusion collection was $61 \cdot 2 \pm 2.9$ when the maximum capacity of the liver to excrete $\mathrm{Mn}$ in bile had not been exceeded. When the maximum biliary excretion of $\mathrm{Mn}$ had been exceeded 34.5, 29.4 and 32.3\% of the infused Mn was recovered in bile from animals A, B and C respectively. During the $6 \mathrm{~h}$ infusion plus $9 \mathrm{~h}$ collection after the end of the infusions at 73.2 and $1760 \mu \mathrm{g} \mathrm{Mn} / \mathrm{min}$ the percentage of $\mathrm{Mn}$ recovered was 62.4 and 79.7 respectively of that infused, leaving $9.9 \mathrm{mg}$ and $128.7 \mathrm{mg}$ of $\mathrm{Mn}$ unaccounted for. The patterns of excretion of $\mathrm{Mn}$ during these two infusions and for $9 \mathrm{~h}$ post infusion are shown in Fig. 1. After the Mn infusion was stopped the changes in the rate of excretion of $\mathrm{Mn}$ in bile could be described in terms of two exponentials with half-lives of 46 and $248 \mathrm{~min}$ after infusion of $73 \mu \mathrm{g} \mathrm{Mn} / \mathrm{min}$ and 32 and $196 \mathrm{~min}$ after infusion $1760 \mu \mathrm{g} \mathrm{Mn} / \mathrm{min}$.

\section{Trace element excretion}

For statistical analysis the trace element excretion values were considered under four ranges of infusion rates: $30-260,960-1100,1570-1700$ and $3470-4320 \mu \mathrm{g} \mathrm{Mn} / \mathrm{min}$. During the 
Table 1. The rate of excretion and concentration of manganese in bile during the last $3 \mathrm{~h}$ of each $6 \mathrm{~h}$ infusion of manganese chloride into the jugular vein and the plasma Mn concentration after $3 h$ of infusion

\begin{tabular}{|c|c|c|c|c|c|}
\hline Animal & $\begin{array}{c}\text { Infusion } \\
\text { rate } \\
(\mu \mathrm{g} / \mathrm{min})\end{array}$ & $\begin{array}{c}\text { Mean Mn } \\
\text { concentration in } \\
\text { bile }(\mu \mathrm{g} / \mathrm{ml})\end{array}$ & $\begin{array}{c}\text { Mean } \mathrm{Mn} \\
\text { excretion } \\
\text { rate }(\mu \mathrm{g} / \mathrm{min})\end{array}$ & $\begin{array}{l}\text { Percentage } \\
\text { Mn excreted } \\
/ \text { min }\end{array}$ & $\begin{array}{c}\text { Plasma Mn } \\
\text { concentration } \\
(\mathrm{ng} / \mathrm{ml})\end{array}$ \\
\hline $\mathbf{A}$ & $\begin{array}{r}30 \\
60 \\
130 \\
240 \\
1100 \\
1700 \\
3900\end{array}$ & $\begin{array}{r}2.7 \\
6.4 \\
13.3 \\
25 \cdot 5 \\
89.9 \\
164.0 \\
187.7\end{array}$ & $\begin{array}{r}20 \\
40 \\
90 \\
160 \\
730 \\
1131 \\
1229\end{array}$ & $\begin{array}{l}66 \cdot 7 \\
66.7 \\
69 \cdot 2 \\
66 \cdot 7 \\
66.4 \\
66.5 \\
31.5\end{array}$ & $\begin{array}{r}* \\
* \\
* \\
* \\
* \\
401 \\
2060\end{array}$ \\
\hline B & $\begin{array}{r}70 \\
260 \\
960 \\
1570 \\
3500 \\
4320\end{array}$ & $\begin{array}{r}4.9 \\
23.9 \\
112.9 \\
197.5 \\
285.3 \\
166.7\end{array}$ & $\begin{array}{r}40 \\
150 \\
660 \\
1240 \\
1820 \\
989\end{array}$ & $\begin{array}{l}57 \cdot 1 \\
57 \cdot 7 \\
68 \cdot 8 \\
79 \cdot 0 \\
52 \cdot 0 \\
22 \cdot 0\end{array}$ & $\begin{array}{r}29 \\
49 \\
176 \\
346 \\
1744 \\
1586\end{array}$ \\
\hline $\mathrm{C}$ & $\begin{array}{r}73 \\
92 \\
950 \\
1656 \\
3470\end{array}$ & $\begin{array}{r}5.6 \\
12.3 \\
113.3 \\
177.9 \\
177.6\end{array}$ & $\begin{array}{r}56 \\
86 \\
650 \\
1184 \\
916\end{array}$ & $\begin{array}{l}71 \cdot 0 \\
93 \cdot 5 \\
68 \cdot 3 \\
71 \cdot 5 \\
26 \cdot 4\end{array}$ & $\begin{array}{r}24 \\
30 \\
160 \\
310 \\
2380\end{array}$ \\
\hline
\end{tabular}

- No values available.

Table 2. Changes in the concentrations of copper, iron and zinc in bile during infusions of $3470-4320 \mu \mathrm{g} \mathrm{Mn} / \mathrm{min}$ into the jugular vein

(Values expressed as percentage of the original concentration)

\begin{tabular}{|c|c|c|c|}
\hline \multirow{2}{*}{$\begin{array}{l}\text { Time after start } \\
\text { of infusion (h) }\end{array}$} & \multicolumn{3}{|c|}{ Trace element } \\
\hline & $\mathrm{Cu}$ & $\mathrm{Fe}$ & $\mathrm{Zn}$ \\
\hline-1 & $100 \cdot 0$ & $100 \cdot 0$ & $100 \cdot 0$ \\
\hline 0 & $98 \cdot 3$ & $102 \cdot 0$ & 126.7 \\
\hline 1 & $60 \cdot 3^{*}$ & $96 \cdot 0$ & $91 \cdot 3$ \\
\hline 2 & $60 \cdot 0^{*}$ & $83 \cdot 7^{*}$ & $121 \cdot 3$ \\
\hline 3 & $51 \cdot 7^{*}$ & $69 \cdot 0^{*}$ & $85 \cdot 3^{*}$ \\
\hline 4 & $36 \cdot 7^{*}$ & $56 \cdot 3^{*}$ & $67 \cdot 3^{*}$ \\
\hline 5 & $30 \cdot 3^{*}$ & $62 \cdot 0^{*}$ & $70 \cdot 0^{*}$ \\
\hline 6 & $36 \cdot 4^{*}$ & $64 \cdot 7^{*}$ & $76 \cdot 7$ \\
\hline 7 & $29 \cdot 6^{*}$ & $80-1$ & 106.7 \\
\hline
\end{tabular}

* Concentration significantly lower than the concentration at the same time during infusion at 1570-1700, $960-1100$ or $30-260 \mu \mathrm{g} \mathrm{Mn} / \mathrm{min} ; \mathrm{P} \leqslant 0.05$.

control periods the mean $( \pm \mathrm{SE})$ concentrations of $\mathrm{Cu}, \mathrm{Fe}, \mathrm{Zn}$ and $\mathrm{Mn}$ in bile were $0.43 \pm 0.02,0.28 \pm 0.01,0.13 \pm 0.04$ and $1.04 \pm 0.05 \mu \mathrm{g} / \mathrm{ml}$ respectively. No significant changes in the excretion of $\mathrm{Cu}, \mathrm{Fe}$ or $\mathrm{Zn}$ occurred during infusion at the three lowest rates, but at $3470-4320 \mu \mathrm{g} \mathrm{Mn} / \mathrm{min}$ there was a significant decrease in the concentrations of all three trace elements in bile. $\mathrm{Cu}$ excretion was affected most while the excretion of zinc was depressed for only $2 \mathrm{~h}$ (Table 2 ). 

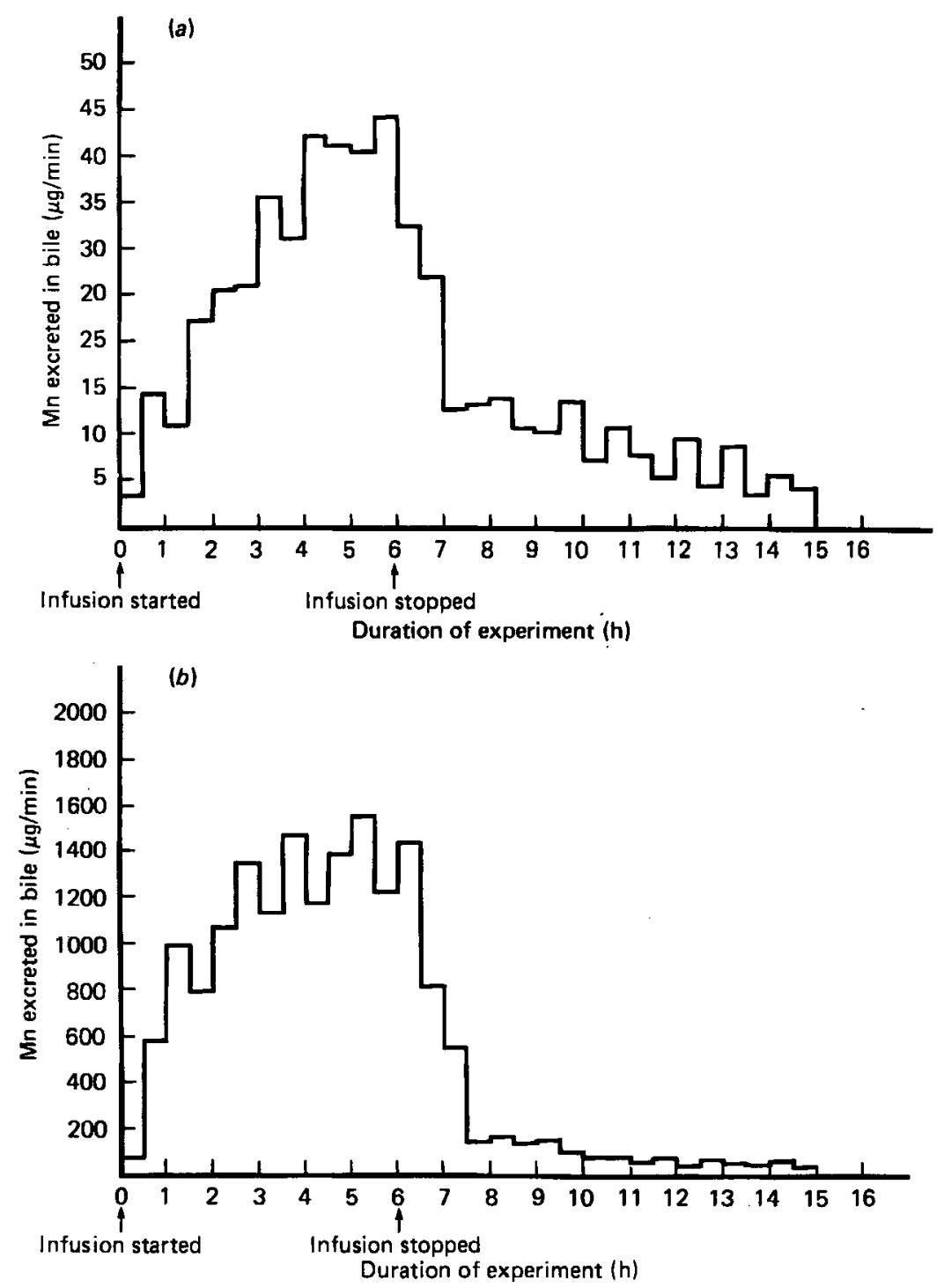

Fig. 1. Manganese excreted in bile ( $\mu \mathrm{g} / \mathrm{min})$ during $6 \mathrm{~h}$ of infusion and $9 \mathrm{~h}$ after infusion of (a) 73.2 and (b) $1760 \mu \mathrm{g} \mathrm{Mn}$ as manganese chloride into jugular veins of steers.

\section{Plasma enzyme and bilirubin concentrations}

There were no consistent changes in plasma enzyme activities or bilirubin concentrations as a result of the $\mathrm{Mn}$ infusions. The concentrations found in samples taken during infusions and control periods have therefore been combined and the mean ( $\pm \mathrm{SE})$ plasma activities of SDH, GDH, $\gamma$ GT and CK were $18 \pm 1,16 \pm 2,12 \pm<1$ and $45 \pm 3$ IU respectively, and the mean ( \pm SE) plasma bilirubin concentration was $1.62 \pm 0.04 \mu \mathrm{mol} / \mathrm{l}$.

\section{DISCUSSION}

The results show that the bovine liver can excrete large quantities of $\mathrm{Mn}$ in bile. Klaassen (1974) found that the maximum excretion rate of $\mathrm{Mn}$ into the bile of rats was $8.5 \mu \mathrm{g} / \mathrm{min}$ per $\mathrm{kg}$ body-weight. In the three steers the mean $( \pm \mathrm{SE})$ maximum excretion rate of $\mathrm{Mn}$ 
was $3.7 \pm 0.5 \mu \mathrm{g} / \mathrm{min}$ per $\mathrm{kg}$ body-weight at the time of the infusion. The values are in reasonable agreement, since the liver constitutes approximately $4.0 \%$ of the body-weight of the rat, and $1.2 \%$ of the body-weight of the cow (Spector, 1956).

Biliary excretion alone would not account for the removal of all infused $\mathrm{Mn}$. When biliary clearance of $\mathrm{Mn}$ was followed for $9 \mathrm{~h}$ after the infusion of 26.2 and $633.6 \mathrm{mg} \mathrm{Mn}$ in $6 \mathrm{~h}, 37.6$ and $20.3 \%$ respectively had not been excreted in bile by the end of the period. In the rat $35 \%$ of $\mathrm{Mn}$ in bile is reabsorbed (Cikrt, 1973). If this percentage reabsorption occurred in cattle and were independent of the concentration of $\mathrm{Mn}$ in bile then the amount of $\mathrm{Mn}$ cleared from the body by excretion would be over-estimated in these experiments. The enterohepatic circulation of $\mathrm{Mn}$ would delay the excretion of $\mathrm{Mn}$ from the body.

Although bile is the major route of excretion of $\mathrm{Mn}$, some loss occurs across the intestinal wall or via pancreatic secretions (Bertinchamps et al. 1966). If the liver was the only route by which Mn was excreted, then at equilibrium the rate of removal by the liver should equal the rate at which Mn was infused. Since only approximately $67 \%$ of the infused Mn was excreted in bile, $33 \%$ was either retained in the tissues of the body or lost by other routes. The kidney was not an important route of loss. During infusion of approximately 4000 $\mu \mathrm{m} \mathrm{Mn} / \mathrm{min}$ urinary $\mathrm{Mn}$ did not increase above $0.6 \mu \mathrm{g} / \mathrm{ml}$. Assuming the steer produced 21 urine during the $6 \mathrm{~h}$ infusion, the maximum loss of $\mathrm{Mn}$ would be only $1.2 \mathrm{mg}(0.08 \%$ of the total infused).

When Mn enters the visceral circulation from the gut or by infusion into a mesenteric vein it is normally removed by the liver during the first passage of the blood through the liver (Gibbons et al. 1976; Sansom et al. 1978). It has been shown that the liver of the adult cow can remove up to $3260 \mu \mathrm{g} \mathrm{Mn} / \mathrm{min}$ as a first pass effect before Mn concentration in hepatic venous plasma increases (Hall \& Symonds, unpublished observations). The livers of the steers should therefore have been capable of extracting all the $\mathrm{Mn}$ presented to them, particularly at the lower infusion rates. However, when $\mathrm{MnCl}_{2}$ is infused into the jugular vein it is most likely that some $\mathrm{Mn}$ is in circulation long enough to be temporarily bound to a plasma protein such as $\alpha$-macroglobulin (Gibbons et al. 1976) and is not immediately removed in passage through the liver. Therefore the excretion rate for $\mathrm{Mn}$ of only $67 \% / \mathrm{min}$ of that infused via the jugular vein may reflect the ability of the liver to extract the unbound Mn from plasma.

Liver damage and cholestasis which had been reported to occur as a result of Mn infusions in rats (Witzleben et al. 1968; Witzleben, 1969), did not occur in the steers. In preliminary studies (Symonds et al. 1979) it was observed that intramesenteric infusions of $\mathrm{MnCl}_{2}$ solution at $69 \mu \mathrm{g} \mathrm{Mn} / \mathrm{min}$ into a steer reduced bile flow-rate, and increased plasma bilirubin and plasma enzyme activities $24 \mathrm{~h}$ later. These observations suggested that the bovine liver was extremely sensitive to $\mathrm{Mn}$ given through the mesenteric vein. The present findings suggest that other factors must have been involved to produce such acute effects and it is evident that the bovine liver is not as susceptible to damage by $\mathrm{Mn}$ as was previously thought.

In summary, the biliary excretion of $\mathrm{Mn}$ in the steer may be increased 200-fold for a few hours with no apparent toxic effects. This facility for increased excretion could cope with an increase in the $\mathrm{Mn}$ concentration in food of 200 -fold (i.e. from approximately 60 to $12000 \mathrm{mg} / \mathrm{kg}$ ) if the percentage absorption of $\mathrm{Mn}$ from the gut remained unchanged. It is very unlikely that ruminants would be subjected to such high concentrations of $\mathrm{Mn}$ in food under normal husbandry conditions. However, the infusions were continued for only $6 \mathrm{~h}$, and it is possible that exposure to a diet containing high concentrations of $\mathrm{Mn}$ over a period of several months could exceed the liver's excretory capacity, particularly if during the same period bilirubin concentrations in plasma became increased of liver damage occurred. 
The authors thank Mrs C. Copp for carrying out enzyme analyses, Mr. C. B. Mallinson for $\mathrm{Cu}, \mathrm{Fe}$ and $\mathrm{Zn}$ analyses, $\mathrm{Mr} \mathrm{P}$. Brookes for bilirubin analyses and $\mathrm{Mr} \mathrm{A}$. Patterson for his assistance in the statistical analysis of the results.

\section{REFERENCES}

Bentley, O. G. \& Phillips, P. H. (1951). J. Dairy Sci. 34, 396.

Bertinchamps, A. J., Miller, S. T. \& Cotzias, G. C. (1966). Am. J. Physiol. 211, 217.

Bourne, F. (1967). Feed Forum. 2, 33.

Carter, J. C. Jr, Miller, W. J., Neathery, M. W., Gentry, R. P., Stake, P. E. \& Blackmon, D. M. (1974). J. Anim. Sci. 38, 1284.

Cikrt, M. (1973). Archs. Toxikol. 31, 51.

Cunningham, G. N., Wise, M. B. \& Barrick, E. R. (1966). J. Anim. Sci. 25, 532.

Egan, A. R. (1972). Aust. J. exp. Agric. Anim. Husb. 12, 131.

Ford, C. M. (1972). Animal Reproduction and Artificial Insemination. VIIth Int. Congr. p. 2011. Munchen.

Gambino, S. R. \& Schreiber, H. (1964). Technicon Symposium, Automation in Analytical Chemistry, Basingstoke, Hants, Technicon Instruments Co. Ltd.

Gibbons, R. A., Dixon, S. N., Hallis, K., Russell, A. M., Sansom, B. F. \& Symonds, H. W. (1976). Biochim. biophys. Acta. 444, 1.

Gubler, C. J., Taylor, D. S., Eichwald, E. J., Cartwright, G. E. \& Wintrobe, M. M. (1954). Proc. Soc. exp. Biol. Med. 86, 223.

Hidiroglou, M. (1979). Can. J. Anim. Sci. 59, 217.

Ivan, M. \& Grieve, C. M. (1975). J. Dairy Sci. 58, 410.

Järvinen, R. \& Ahlström, A. (1975). Med. Biol. 53, 93.

Jendrassik, L. \& Grof, P. (1938). Biochem. Z. 81, 297.

Kimura, M., Yagi, N. \& Hokawa, Y. (1978). J. Toxic. Environ. Hlth 4, 701.

Klaassen, C. D. (1974). Toxicol. Appl. Pharmacol. 29, 458.

Leach, R. M. \& Lilburn, M. S. (1978). Wld Rev. Nutr. Diet. 32, 124.

Rojas, M. A., Dyer, I. A. \& Cassatt, W. A. (1965). J. Anim. Sci. 24, 664.

Sansom, B. F., Symonds, H. W. \& Vagg, M. J. (1978). Res. vet. Sci. 24, 366.

Spector, W. D. (1956). (editor). In Handbook of Biological Data, p. 163. Philadelphia and London: W. B. Saunders Co.

Symonds, H. W., Vagg, M. J. \& Mather, D. L. (1979). Proc. Nutr. Soc. 38, 21 A.

Watson, L. J., Ammerman, C. B., Feaster, J. P. \& Roessler, C. E. (1973). J. Anim. Sci. 36, 131.

Witzleben, C. L. (1969). Am. J. Path. 57, 617.

Witzleben, C. L. (1971). Am. J. Path. 62, 181.

Witzleben, C. L., Pitlick, P., Bergmeyer, J. \& Benoit, R. (1968). Am. J. Path. 53, 404. 